MINERALOGIA, 48, No 1-4: 71-86 (2017)

DE DE GRUYTER OPEN

DOI: 10.1515/mipo-2017-0013

www.Mineralogia.pl

MINERALOGICAL SOCIETY OF POLAND

POLSKIE TOWARZYSTWO MINERALOGICZNE

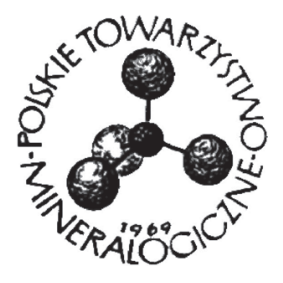

Original paper

\title{
Efficiency of $\mathrm{Pb}(\mathrm{II})$ and $\mathrm{Mo}(\mathrm{VI})$ removal by kaolinite impregnated with zero-valent iron particles
}

\author{
Karolina Rybka ${ }^{1}$, Katarzyna Suwała ${ }^{1}$, Paulina Maziarz $^{1 *}$, Jakub Matusik ${ }^{1}$ \\ ${ }^{I}$ A GH University of Science and Technology, Faculty of Geology, Geophysics and Environmental Protection, \\ Department of Mineralogy, Petrography and Geochemistry, al. Mickiewicza 30, Krakow, 30 059, Poland \\ * Corresponding author \\ e-mail:pmaziarz@agh.edu.pl
}

Received: April 13, 2017

Received in revised form: August 29, 2017

Accepted: August 29, 2017

Available online: September 30, 2017

\begin{abstract}
In this work, kaolinite modified with zero-valent iron was synthesized and used as a sorbent for $\mathrm{Pb}(\mathrm{II})$ and $\mathrm{Mo}(\mathrm{VI})$ removal from aqueous solutions. The obtained material was characterized by X-ray diffraction (XRD) and Fourier transform infrared (FTIR) spectroscopy. The methods revealed successful modification by the $\mathrm{Fe}^{0}$ particles precipitation on the surface of well-ordered kaolinite. The sorption experiment results showed a significant increase of sorption capacity in relation to the raw kaolinite. The kaolinite with $25 \%$ content of $\mathrm{Fe}^{0}$ was found to be the best material for $\mathrm{Pb}(\mathrm{II})$ and $\mathrm{Mo}(\mathrm{VI})$ removal, resulting in approximately $500 \mathrm{mmol} \cdot \mathrm{kg}^{-1}$ and $350 \mathrm{mmol} \cdot \mathrm{kg}^{-1}$ sorption, respectively. The possible mechanisms responsible for metals' removal were identified as reduction by $\mathrm{Fe}^{0}$ 'core' and adsorption on the iron hydroxides 'shell'. The study indicated that the obtained material is capable of efficient $\mathrm{Pb}(\mathrm{II})$ and $\mathrm{Mo}(\mathrm{VI})$ removal and may be an interesting alternative to other methods used for heavy metals' removal.
\end{abstract}

Key-words: zero-valent iron particles, kaolinite, adsorption, $\mathrm{Pb}(\mathrm{II}), \mathrm{Mo}(\mathrm{VI})$

\section{Introduction}

The increasing contamination of the environment with heavy metals has become a public health concern. This is because of their persistent nature and tendency to accumulate in living tissues. Therefore, there is a high demand for designing efficient methods of technological wastewater treatment. 
Various treatment technologies have been reported for heavy metals' removal, such as chemical precipitation (Meunier et al. 2006), oxidation-reduction (Ramos et al. 2009), adsorption (Rui et al. 2016), ion exchange (Oehmen et al. 2006) electrochemical treatment (Meunier et al. 2006), physical membranes (Zondervan, Roffel 2007), and filtration (Leupin, Hug 2005).

In practice, most of these methods turn out to be inefficient and damaging to the environment. Moreover, they have high energy requirements and may involve the use of harmful chemical reagents. Among the above methods, adsorption processes are one of the most commonly used because of their simplicity, relatively low cost, high effectiveness and wide range of possible applications in water treatment. Adsorption can be conducted with the use of many materials, both of organic and inorganic origin. Multiple methods of their modification are known, which have led to the improvement of their sorption properties. Many conventional and unconventional adsorbents have been used for heavy metals' removal, including layered double hydroxides (LDH) (You et al. 2001; Hudcova et al. 2016), clay minerals (Suraj et al. 1998; Bhattacharyya, Gupta 2006; Zhang, Hou 2008; Üzüm et al. 2009), zeolites (Erdem et al. 2004; Szala et al. 2015), activated carbon (Patnukao et al. 2008; Xu et al. 2008), and graphene oxides (Ren et al. 2013; Liu et al. 2014).

Clay minerals are cost-effective, widely available and can be easily modified. Kaolinite is a 1:1 layered aluminum silicate clay composed of tetrahedral and octahedral sheets. The layers are linked together through hydrogen bonding between the oxygen atoms of the tetrahedral sheet and the $\mathrm{OH}$ groups of the octahedral sheet. Its chemical composition is $\mathrm{Al}_{2} \mathrm{Si}_{2} \mathrm{O}_{5}(\mathrm{OH})_{4}$. To date, the kaolin group minerals have been reported as easily modified adsorbents for heavy metals' removal (e.g. Suraj et al. 1998; Saada et al. 2003; Bhattacharyya, Gupta 2006, 2007; Unuabonah et al. 2008; Wang et al. 2015).

In recent years, research on zero-valent iron nanoparticles (nZVI) has been dynamically developed. Earlier experiments confirmed efficiency in heavy metals' removal from water solutions, which is a result of nZVI's high reactivity resulting from abundant reactive surface sites as well as the possibility of particle size control (Ponder et al. 2000; Üzüm et al. 2008; Li et al. 2016). Small particle size and powder state restrict nZVI application in real environmental conditions. The nZVI can also agglomerate and react with surrounding media, which results in poor mobility and subsequently in low removal efficiency. This is also connected with difficulties in nZVI migration into contaminated areas (Grieger et al. 2010). To minimize this effect, special composites, with the use of conventional adsorbents are prepared, which play the role of a support for nZVI (Shi et al. 2011; Kim et al. 2013; Wang et al. 2015).

The objective of this study was to obtain a kaolinite zero-valent iron composite capable of $\mathrm{Pb}(\mathrm{II})$ and $\mathrm{Mo}(\mathrm{VI})$ adsorption. Both elements can cause irreversible health effects for humans exposed to such a contaminated environment. Materials with different concentrations of zero-valent iron particles were prepared. The sorption experiments of $\mathrm{Pb}$ (II) and $\mathrm{Mo}(\mathrm{VI})$ were conducted to evaluate the adsorption efficiency, and the mechanisms responsible for $\mathrm{Pb}(\mathrm{II})$ and $\mathrm{Mo}(\mathrm{VI})$ removal. 


\section{Materials and methods}

\subsection{Materials}

For the experiments, kaolinite sample collected from the Maria III kaolinite deposit (Lower Silesia Region, Poland) was used (K). Earlier studies revealed that the sample is mainly composed of kaolinite of high structural order and has a small admixture of illite and quartz (Koteja et al. 2015). The kaolinite was used as obtained, having a fraction $<40 \mu \mathrm{m}$, without any purification. All used reagents were analytically graded. During the experiments, redistilled water was used.

\subsection{Preparation of $\mathrm{KFe}^{0}$ composite}

The synthesis of kaolinite composites followed a procedure reported earlier by Wang and Zhang (1997). The nZVI chemical synthesis can be described using the following reaction:

$$
2 \mathrm{FeCl}_{3}+6 \mathrm{NaBH}_{4}+18 \mathrm{H}_{2} \mathrm{O} \rightarrow 2 \mathrm{Fe}^{0}+6 \mathrm{NaCl}+6 \mathrm{~B}(\mathrm{OH})_{3}+21 \mathrm{H}_{2}
$$

In the experiment, the iron(III) chloride was used as an iron precursor and $1 \mathrm{M}$ sodium borohydride as a reducing agent (Üzüm et al. 2009). In order to prevent iron oxidation, the synthesis was conducted in an argon atmosphere and at room temperature. The mass ratio of nZVI to kaolinite sample was set to 5,10 and $25 \mathrm{wt} \%$. The synthesis was performed in a round-bottom three-neck flask. Firstly, $150 \mathrm{ml}$ of $\mathrm{Fe}(\mathrm{III})$ solution was prepared in ethanol. Then, $4.75 \mathrm{~g}$ of kaolinite was slowly added to the solution to obtain a homogenous suspension. In the next step, the sodium borohydride solution was prepared in $50 \mathrm{ml}$ of redistilled water and added dropwise to the suspension of aqueous iron(III) chloride and kaolinite. The ethanol to water ratio was 3:1. The reductive agent was added in a $10 \%$ excess to ensure the complete reduction of $\mathrm{Fe}(\mathrm{III})$ to $\mathrm{Fe}^{0}$. The final products $\left(\mathrm{KFe}^{0}\right.$, $\mathrm{KFe}^{0} 10$, and $\left.\mathrm{KFe}^{0} 25\right)$ were centrifuged (10 min, $4200 \mathrm{rpm}$ ), washed with ethanol and dried at $60^{\circ} \mathrm{C}$ overnight.

TABLE 1

List of reagents used during synthesis of the $\mathrm{KFe}^{0}$ samples, with amounts calculated from the stoichiometry of the reaction (1).

\begin{tabular}{llllll}
\hline Sample & $\mathrm{Fe}^{0}$ amount [\%] & Kaolinite $[\mathrm{g}]$ & $\mathrm{FeCl}_{3} \cdot 6 \mathrm{H}_{2} \mathrm{O}[\mathrm{g}]$ & $\mathrm{NaBH}_{4}[\mathrm{~g}]$ & $\begin{array}{l}\mathrm{NaBH}_{4} \text { (enlarged by } \\
10 \%)[\mathrm{g}]\end{array}$ \\
\hline $\mathrm{KFe}^{0} 5$ & $5 \%$ & 4.75 & 1.21 & 0.505 & 0.655 \\
$\mathrm{KFe}^{0} 10$ & $10 \%$ & 4.5 & 2.42 & 1.01 & 1.20 \\
$\mathrm{KFe}^{0} 25$ & $25 \%$ & 3.75 & 6.04 & 2.525 & 2.777 \\
\hline
\end{tabular}




\subsection{Characterization methods}

The structural analysis of the mineral hybrids was done using X-ray diffraction (XRD) and Fourier transform infrared (FTIR) spectroscopy. The XRD patterns of powdered samples were recorded in the range of $2-73^{\circ} 2 \theta$ with $0.05^{\circ} 2 \theta$ steps, using a RIGAKU Miniflex 600 diffractometer with $\mathrm{CuK} \alpha(\lambda=1.5418 \AA)$ radiation. The FTIR spectra of powdered samples were obtained with a Nicolet 6700 (Thermo Scientific). The IR spectra were recorded in transmission mode using $\mathrm{KBr}$ pellets (1 $\mathrm{mg}$ sample per $200 \mathrm{mg} \mathrm{KBr}$ ). For each measurement, 64 scans were collected in the range of $4000-400 \mathrm{~cm}^{-1}$ and $4 \mathrm{~cm}^{-1}$ resolution. The samples were also characterized by Scanning Electron Microscopy (SEM) FEI Quanta 200 FEG with EDS detector. Samples were prepared by placing powdered material on a carbon tape. The X-ray Fluorescence (XRF) results were obtained by using a WD-XRF ZSX Primus II Rigaku spectrometer and SQX calculation software.

\subsection{Adsorption isotherms}

The adsorption studies were carried out for $\mathrm{Pb}(\mathrm{II})$ and $\mathrm{Mo}(\mathrm{VI})$ using initial concentrations in the range of $0.1-25.0 \mathrm{mmol} \cdot \mathrm{L}^{-1}$. The initial $\mathrm{pH}$ was adjusted to 5.0 using $\mathrm{KOH}$ and $\mathrm{HNO}_{3}$ solutions. The $\mathrm{Pb}(\mathrm{II})$ and $\mathrm{Mo}(\mathrm{VI})$ stock solutions were prepared by dissolving $\mathrm{Pb}\left(\mathrm{NO}_{3}\right)_{2} \cdot 4 \mathrm{H}_{2} \mathrm{O}$ and $\mathrm{Na}_{2} \mathrm{MoO}_{4} \cdot 2 \mathrm{H}_{2} \mathrm{O}$, respectively. The $\mathrm{KFe}^{0}$ samples were added in the amount of $50 \mathrm{mg}$ to $2.5 \mathrm{ml}$ of metal solution (solid/liquid ratio of $20 \mathrm{~g} \cdot \mathrm{L}^{-1}$ ). The suspensions were shaken for $24 \mathrm{~h}$ at room temperature. Afterwards, the samples were centrifuged (5 min, $10000 \mathrm{rpm})$. The $\mathrm{Pb}(\mathrm{II})$ and $\mathrm{Mo}(\mathrm{VI})$ concentrations in equilibrium solutions were determined using the Atomic Absorption Spectroscopy (AAS) method: GBC SavanthAA spectrometer.

\subsection{Adsorption kinetics}

In the kinetic studies, a $1 \mathrm{mmol} \cdot \mathrm{L}^{-1}$ solution of $\mathrm{Pb}(\mathrm{II}) / \mathrm{Mo}(\mathrm{VI})$ was used. The initial $\mathrm{pH}$ was set to $5.0 \pm 0.2$. Then, $100 \mathrm{mg}$ of each material sorbent was mixed with $5 \mathrm{ml}$ of the solution $\left(20 \mathrm{~g} \cdot \mathrm{L}^{-1}\right.$ concentration) using a magnetic stirrer $(100 \mathrm{rpm})$ at room temperature. The suspension samples were collected after the reaction at $0.5,1,2,4,6,8,10,15,30$ and $60 \mathrm{~min}$, and afterwards they were immediately filtered using a $0.22 \mu \mathrm{m}$ PES membrane. The obtained kinetic data were evaluated by using pseudo-first-order (Eq. 2) and pseudosecond-order (Eq. 3) equations:

$$
\begin{gathered}
\log \left(\mathrm{q}_{\mathrm{eq}}-\mathrm{q}_{\mathrm{t}}\right)=\log \mathrm{q}_{\mathrm{eq}}-\left(\mathrm{k}_{1} \mathrm{t}\right) / 2.303 \\
\mathrm{t} / \mathrm{q}_{\mathrm{t}}=1 /\left(\mathrm{k}_{2} \mathrm{q}_{\mathrm{eq}}{ }^{2}\right)+\mathrm{t} / \mathrm{q}_{\mathrm{eq}}
\end{gathered}
$$

where $\mathrm{q}_{\mathrm{eq}}$ and $\mathrm{q}_{\mathrm{t}}$ are the sorption capacity at equilibrium and at time $\mathrm{t}\left(\mathrm{mmol} \cdot \mathrm{kg}^{-1}\right)$, respectively; and $\mathrm{k}_{1}\left(\mathrm{~min}^{-1}\right)$ and $\mathrm{k}_{2}\left(\mathrm{~kg} \cdot \mathrm{mmol}^{-1} \cdot \mathrm{min}^{-1}\right)$ are the first order and second order rate constants, respectively. 


\section{Results and discussion}

\subsection{XRD results}

The XRD analysis was conducted in order to investigate the mineralogical composition and the quality of the prepared materials (Fig. 1). The diffractogram of pure kaolinite showed the major basal spacing peak at approximately $7.18 \AA$ A. Moreover, a group of wellresolved peaks in the $19-242 \theta$ range was observed, indicating a high structural order of the mineral. After loading with zero-valent iron particles, the position of kaolinite basal reflection as well as the above-mentioned group of peaks did not change, confirming that the interlayer space was not altered. In turn, reflections at $2.92 \AA$ and $2.03 \AA$ were observed, attesting to the successful formation of $\mathrm{Fe}^{0}$ particles exclusively on the kaolinite surface (Prabu, Parthiban 2013). It was noticed that the intensity of the reflections attributed to the $\mathrm{Fe}^{0}$ formation increased with the increase of $\mathrm{Fe}^{0}$ particles' loading. At

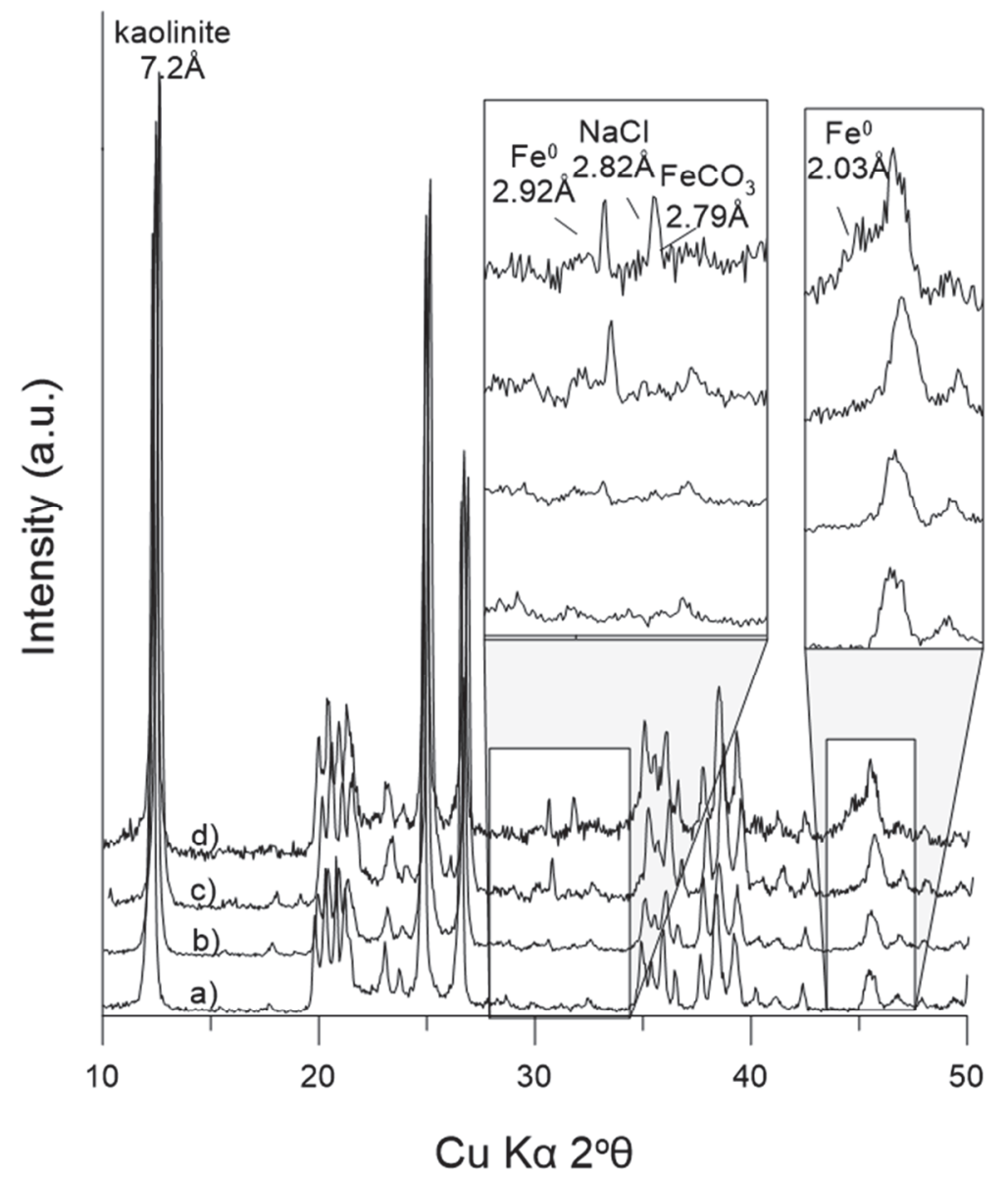

Fig. 1. The XRD patterns of (a) pure kaolinite sample (K) and $\mathrm{KFe}^{0}$ composites, (b) $\mathrm{KFe}^{0} 5$, (c) $\mathrm{KFe}^{0} 10$, and (d) $\mathrm{KFe}^{0} 25$. 
higher $\mathrm{Fe}^{0}$ loading (25 wt\%), an appearance of additional sharp reflection at approximately $2.82 \AA$ was observed. Its presence can be connected with $\mathrm{NaCl}$ precipitation in the reaction of sodium (from the reducing agent $\mathrm{NaBH}_{4}$ ) with chlorides (from $\mathrm{FeCl}_{3} \cdot 6 \mathrm{H}_{2} \mathrm{O}$ ). Also, a small peak at $2.79 \AA$ could be observed, especially in a sample with the highest $\mathrm{Fe}^{0}$ loading. This is connected with the presence of siderite, precipitated in the iron reaction with adsorbed atmospheric $\mathrm{CO}_{2}$.

\subsection{FTIR results}

The spectrum of pure kaolinite showed four distinct bands in the $\mathrm{OH}$ stretching region at $3620,3652,3668$, and $3695 \mathrm{~cm}^{-1}$. These bands confirmed the presence of well-ordered kaolinite, which is in agreement with the XRD patterns. The positions of these bands after $\mathrm{Fe}^{0}$ loading did not change. In turn, an intensity increase of the absorption band centered at approximately $3423 \mathrm{~cm}^{-1}$ corresponding to the $\mathrm{O}-\mathrm{H}$ vibration of the absorbed $\mathrm{H}_{2} \mathrm{O}$ molecules was noticed. The intensity of this band increased systematically with the amount of loaded $\mathrm{Fe}^{0}$, indicating higher water adsorption affinity for the obtained kaolinite-based composites (Balan et al. 2001). In the range of 1000-400 $\mathrm{cm}^{-1}$, the characteristic vibrations attributed to kaolinite aluminum silicate framework were noticed. Their positions and intensity were not affected by the $\mathrm{Fe}^{0}$ precipitation, indicating a lack of structural perturbations within the 1:1 layer.

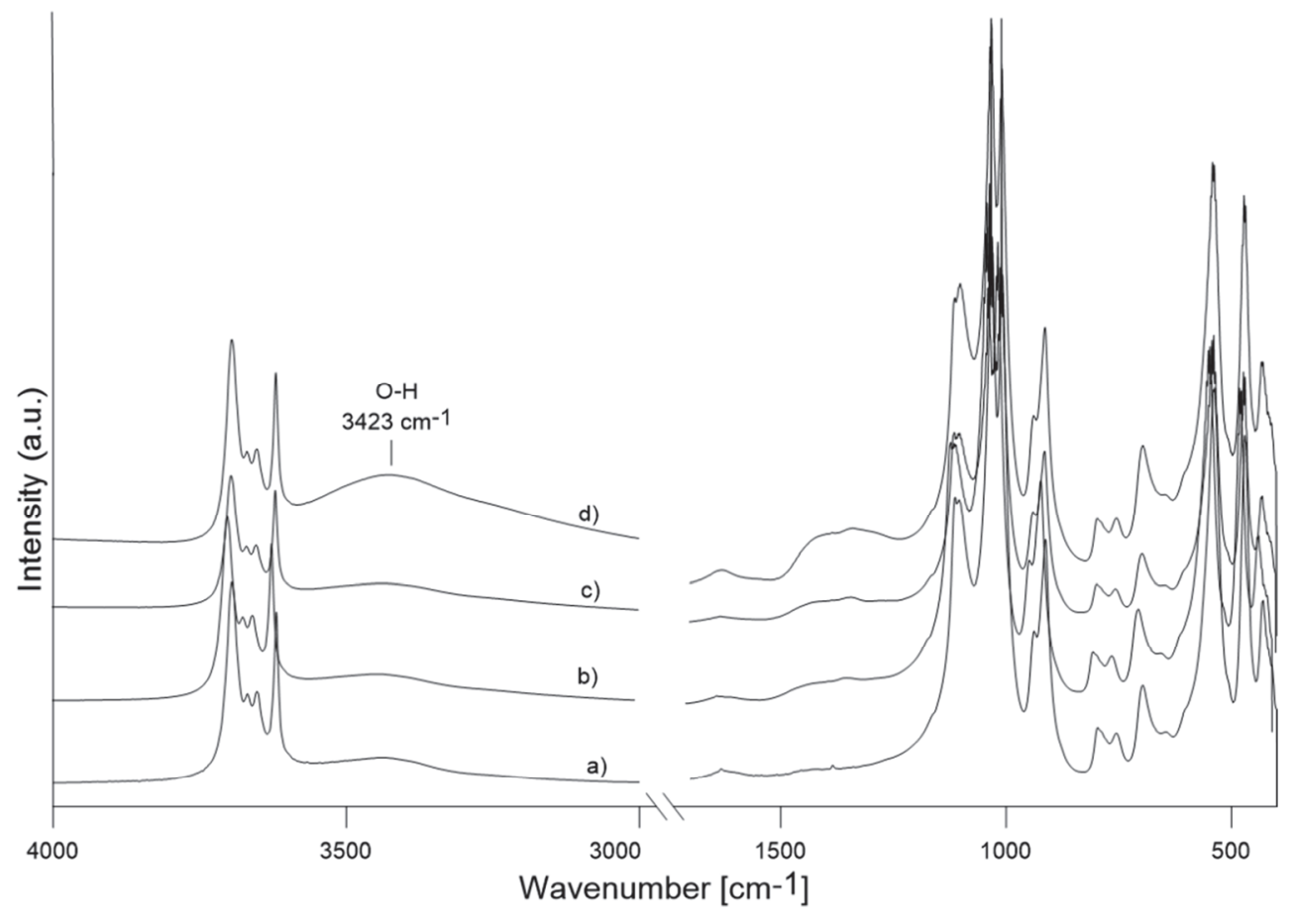

Fig. 2. The FTIR spectra of (a) pure kaolinite sample (K) and $\mathrm{KFe}^{0}$ composites, (b) $\mathrm{KFe}^{0} 5$, (c) $\mathrm{KFe}^{0} 10$, and (d) $\mathrm{KFe}^{0} 25$. 


\subsection{SEM/EDS results}

Figure 3 shows the SEM images of the $\mathrm{KFe}^{0}$ samples. The brighter areas indicate regions having high electron density and are recognized as zero-valent iron $\left(\mathrm{Fe}^{0}\right)$. Figure $3 \mathrm{a}$ shows agglomerated kaolinite particles approximately $100 \mu \mathrm{m}$ in size with $\mathrm{Fe}^{0}$ particles on the surface. The fibrous phase covering the kaolinite particles, which can be seen in Figure $3 \mathrm{~b}-\mathrm{d}$, was recognized as iron oxyhydroxides. This confirmed that $\mathrm{Fe}^{0}$ underwent partial oxidation in the applied experimental conditions. Figure $3 \mathrm{c}$ and $3 \mathrm{~d}$ show $\mathrm{Fe}^{0}$ particles, where the dimensions do not exceed $5 \mu \mathrm{m}$, although it should be noticed that the particle size was not unimodal. As reported earlier, the physical parameters of $\mathrm{Fe}^{0}$ particles such as size, dimension, and crystallinity can influence the rate of iron oxidation (Yan et al. 2012).
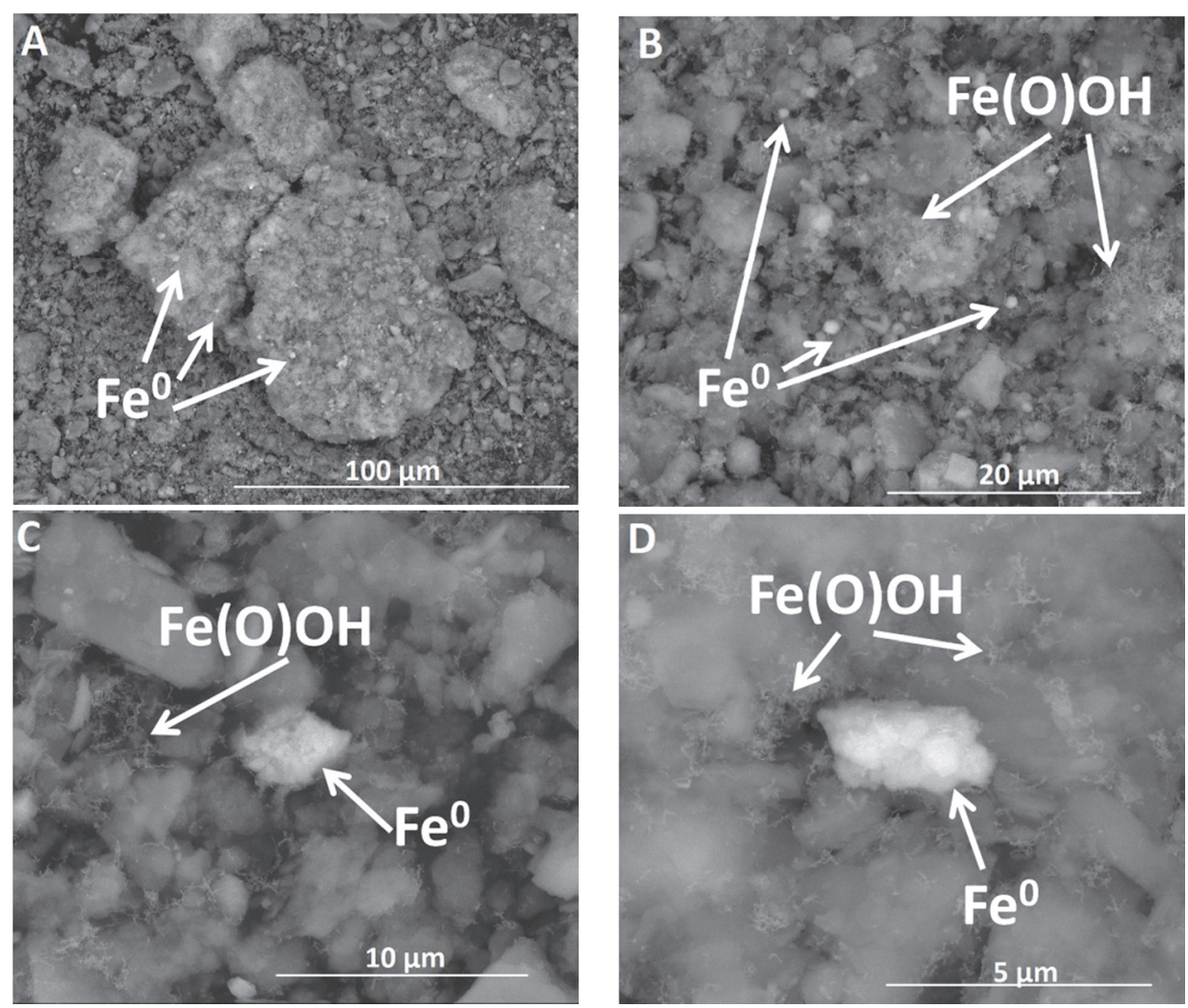

Fig. 3. The SEM images of $\mathrm{KFe}^{0}$ samples.

\subsection{XRF results}

Table 2 comprises the results of the XRF analysis of the $\mathrm{K}$ and $\mathrm{KFe}^{0}$ samples. An increasing amount of iron in the samples indirectly indicates an increasing amount of $\mathrm{Fe}^{0}$ in the composites, but to calculate the iron content for each sample the Fe content in $\mathrm{K}$ was subtracted. The $\mathrm{Fe}^{0}$ loading for the $\mathrm{KFe}^{0} 5, \mathrm{KFe}^{0} 10$, and $\mathrm{KFe}^{0} 25$ samples was calculated to 
be $2.84 \%, 5.40 \%$, and $12.06 \%$, respectively. The results show that the evaluated values were nearly two times lower than the assumed ones. This may be due to insufficient reaction conditions, which favored the incomplete reduction of $\mathrm{Fe}(\mathrm{III})$ to $\mathrm{Fe}^{0}$. The presence of $\mathrm{Na}$ and $\mathrm{Cl}$ in the $\mathrm{KFe}^{0}$ samples is connected with substrates used for the synthesis.

TABLE 2

The XRF results for $\mathrm{K}$ and $\mathrm{KFe}^{0}$ samples.

\begin{tabular}{lllll}
\hline & $\mathrm{K}$ & $\mathrm{K}-\mathrm{Fe}^{0} 5 \%$ & $\mathrm{~K}-\mathrm{Fe}^{0} 10 \%$ & $\mathrm{~K}-\mathrm{Fe}^{0} 25 \%$ \\
\hline $\mathrm{Mg}$ & 0.062714 & 0.088583 & 0.057588 & 0.051317 \\
$\mathrm{Al}$ & 10.37321 & 10.05265 & 9.256797 & 6.950239 \\
$\mathrm{Si}$ & 27.01694 & 23.12744 & 21.20204 & 16.07153 \\
$\mathrm{P}$ & 0.061971 & 0.034215 & 0.030222 & 0.023828 \\
$\mathrm{~S}$ & 0.025669 & 0.032557 & 0.024267 & 0.02643 \\
$\mathrm{~K}$ & 0.357376 & 0.300387 & 0.265894 & 0.216833 \\
$\mathrm{Ca}$ & 0.082189 & 0.055388 & 0.051743 & 0.032518 \\
$\mathrm{Ti}$ & 0.399156 & 0.339702 & 0.304941 & 0.230684 \\
$\mathrm{Cr}$ & 0.008108 & 0.006637 & 0.006295 & 0.002771 \\
$\mathrm{Fe}$ & 0.241649 & 3.084886 & 5.63874 & 12.3015 \\
$\mathrm{Sr}$ & 0.103162 & 0.081346 & 0.075934 & 0.057923 \\
$\mathrm{Zr}$ & 0.011253 & 0.068479 & 0.055375 & 0.048935 \\
$\mathrm{~Pb}$ & 0.05867 & 0.046137 & 0.044373 & 0.036111 \\
$\mathrm{Na}$ & - & 0.534987 & 0.615329 & 0.628312 \\
$\mathrm{Cl}$ & - & 0.2277 & 0.1064 & 1.0743 \\
\hline
\end{tabular}

\subsection{Adsorption experiment results}

As shown in Figure 4a, the removal of $\mathrm{Pb}$ (II) varied with the amount of zero-valent iron particles. The sorption increased with increasing concentration of the $\mathrm{Fe}^{0}$. For the highest $\mathrm{Pb}$ (II) initial concentrations, a slight decrease of adsorption was observed. The highest sorption capacity estimated from the isotherm plateau was observed for the $\mathrm{KFe}^{0} 25$ sample and was equal to $\sim 500 \mathrm{mmol} \cdot \mathrm{kg}^{-1}$. The observed values were much higher than observed for the pure Maria III kaolinite, which was equal to $\sim 10 \mathrm{mmol} \cdot \mathrm{kg}^{-1}$ (Koteja, Matusik 2015). This proved that kaolinite coated with zero-valent iron particles had a significantly higher adsorption affinity toward $\mathrm{Pb}(\mathrm{II})$ than the raw kaolinite. After $24 \mathrm{~h}$ of the adsorption experiment, the $\mathrm{pH}$ increased significantly. It reached values close to 9.0 for the $\mathrm{KFe}^{0} 5$ and $\mathrm{KFe}^{0} 10$, and 6.0 for the $\mathrm{KFe}^{0} 25$ (Fig. 4a). Along with the increase of sorption, the $\mathrm{pH}$ decreased. Only for the $\mathrm{KFe}^{0} 25$ sample did the $\mathrm{pH}$ drop below the initial $\mathrm{pH}$, which was set to 5.0 . 

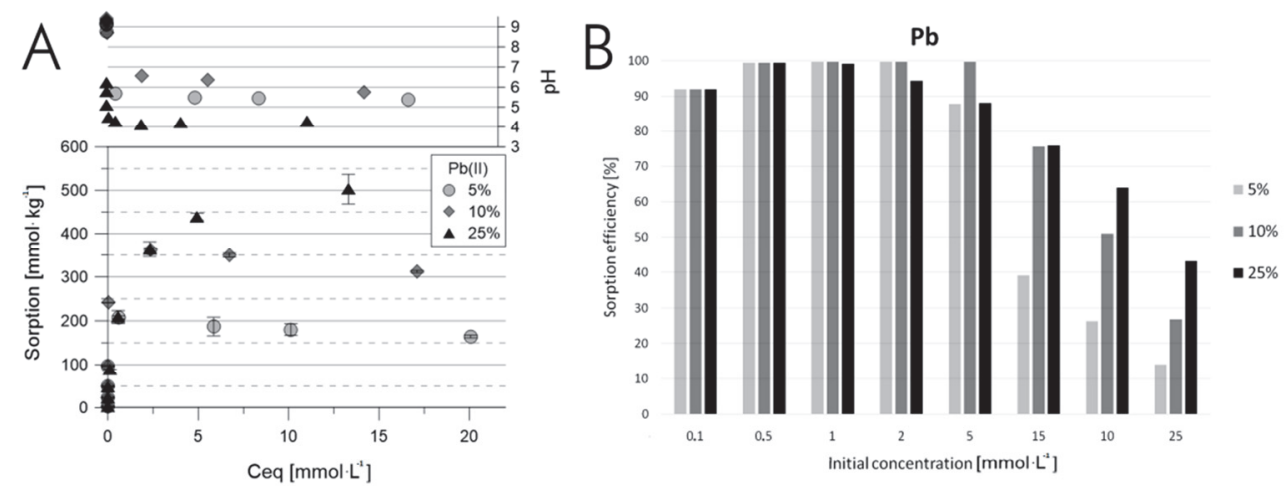

Fig. 4. The $\mathrm{Pb}(\mathrm{II})$ adsorption isotherms and $\mathrm{pH}$ range for $\mathrm{KFe}^{0} 5, \mathrm{KFe}^{0} 10$, and $\mathrm{KFe}^{0} 25$ (a), and the sorption efficiency (b).

All the used materials showed a removal percentage close to $100 \%$ for the $\mathrm{Pb}$ (II) concentrations up to $2 \mathrm{mmol} \cdot \mathrm{L}^{-1}$ (Fig. $4 \mathrm{~b}$ ). As the $\mathrm{Pb}$ (II) initial concentration increased, the $\mathrm{Pb}$ (II) uptake decrease was observed. This decrease was more pronounced in the case of sorption onto $\mathrm{KFe}^{0} 5$ and $\mathrm{KFe}^{0} 10$ where the final removal was equal to $14 \%$ and $26 \%$, respectively, for the initial concentration of $25 \mathrm{mmol} \cdot \mathrm{L}^{-1}$. Whereas for the $\mathrm{KFe}^{0} 25$, the removal efficiency decreased to $43 \%$ for the highest $\mathrm{Pb}$ (II) concentration.

The adsorption of anions by kaolinite including $\mathrm{Mo}(\mathrm{VI})$ ionic species is possible only to a small extent, due to the lack of its anion-exchange properties (Zachara et al. 1988). The coating of kaolinite with zero-valent iron particles significantly improved the sorption capacity of $\mathrm{Mo}(\mathrm{VI})$. In analogy to $\mathrm{Pb}(\mathrm{II})$, the sorption increased with the amount of loaded $\mathrm{Fe}^{0}$. The maximal values measured at the highest initial concentrations were in the range of $175-220 \mathrm{mmol} \cdot \mathrm{L}^{-1}$ for the $\mathrm{KFe}^{0} 5$ and $\mathrm{KFe}^{0} 10$. The highest adsorption capacity, equal to $350 \mathrm{mmol} \cdot \mathrm{kg}^{-1}$, was observed for the $\mathrm{KFe}^{0} 25$. These values were much higher than those observed for pure and modified kaolinites with other anions, including $\mathrm{As}(\mathrm{V}), \mathrm{P}(\mathrm{V}), \mathrm{S}(\mathrm{VI})$, and N(V) (Matusik 2014). Previous sorption studies indicated that sorption capacity was equal to $5 \mathrm{mmol} \cdot \mathrm{kg}^{-1}$ for the initial $\mathrm{Mo}(\mathrm{VI})$ concentration of $5 \mathrm{mmol} \cdot \mathrm{L}^{-1}$ (Rybka 2017).

In all cases, the final $\mathrm{pH}$ was higher than the starting value of 5.0. The $\mathrm{pH}$ increase was the highest for the lower $\mathrm{Mo}(\mathrm{VI})$ concentrations and equal to $\sim 9.0$. In turn, the increase was less significant for higher concentrations where the final value was in the $5-7$ range. The $\mathrm{pH}$ range after the sorption experiment varied between 5.5 and 9.0. The final $\mathrm{pH}$ can result from iron oxidation and the production of hydroxyl ions (Crane, Scott 2012), and can be influenced by the metal concentration in the solution.

As shown in Figure 5B, the removal percentage for $\mathrm{KFe}^{0} 25$ was equal to $80 \%$ for the lowest $\mathrm{Mo}(\mathrm{VI})$ concentration. Along with the $\mathrm{Mo}(\mathrm{VI})$ concentration increase, the percentage uptake decreased to approximately $35-50 \%$. The $\mathrm{KFe}^{0} 25$ seemed to have the highest percentage removal, whereas the $\mathrm{KFe}^{0} 5$ and $\mathrm{KFe}^{0} 10$ showed similar results for $\mathrm{Mo}(\mathrm{VI})$ concentrations in the range of $1-25 \mathrm{mmol} \cdot \mathrm{L}^{-1}$. 

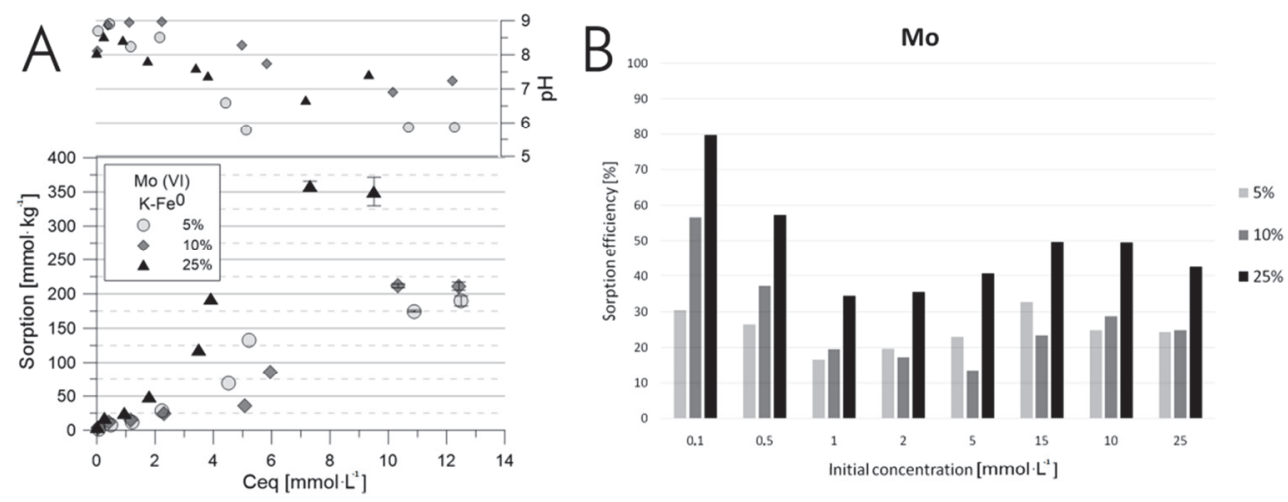

Fig. 5. The Mo(VI) adsorption isotherms and $\mathrm{pH}$ range for $\mathrm{KFe}^{0} 5, \mathrm{KFe}^{0} 10$, and $\mathrm{KFe}^{0} 25$ (a), and the sorption efficiency (b).

\subsection{Adsorption kinetics}

For the $\mathrm{Pb}(\mathrm{II})$ sorption experiment, after only $30 \mathrm{sec}$ all $\mathrm{Pb}(\mathrm{II})$ was adsorbed by each material $\left(\mathrm{KFe}^{0} 5, \mathrm{KFe}^{0} 10\right.$, and $\left.\mathrm{KFe}^{0} 25\right)$. The results of the $\mathrm{Mo}(\mathrm{VI})$ sorption kinetic experiment are shown in Figure 6. The Mo(VI) sorption proceeded with a lower rate and kinetics depending on the material. For the $\mathrm{KFe}^{0} 5$, the maximum uptake of $65 \%$ was reached after $60 \mathrm{~min}$, but after $15 \mathrm{~min}$ the sorption efficiency was equal to $55 \%$. For the $\mathrm{KFe}^{0} 10$ and $\mathrm{KFe}^{0} 25$ materials, $100 \%$ sorption efficiency of $\mathrm{Mo}(\mathrm{VI})$ occurred after 8 min and $5 \mathrm{~min}$, respectively. As shown in Table 3, the kinetic data for the Mo(VI) fit much better to a pseudo-second-order equation in the case of the $\mathrm{KFe}^{0} 10$ and $\mathrm{KFe}^{0} 25$ materials. However, for the $\mathrm{KFe}^{0} 5$ agreement both with the pseudo-first-order and pseudo-secondorder equations was observed.

TABLE 3

The kinetic models' parameters.

\begin{tabular}{lllll}
\hline \multirow{2}{*}{ Sample } & \multicolumn{2}{c}{ Pseudo-first-order } & \multicolumn{2}{l}{ Pseudo-second-order } \\
& $\mathrm{R}^{2}$ & $\mathrm{k}_{2}$ & $\mathrm{q}_{\mathrm{eq}}$ & $\mathrm{R}^{2}$ \\
\hline $\mathrm{KFe}^{0} 5$ & 0.9715 & 0.0131 & 18.48 & 0.994 \\
$\mathrm{KFe}^{0} 10$ & 0.3928 & 0.0089 & 28.90 & 0.9836 \\
$\mathrm{KFe}^{0} 25$ & 0.2168 & 0.0200 & 34.48 & 0.9941 \\
\hline
\end{tabular}




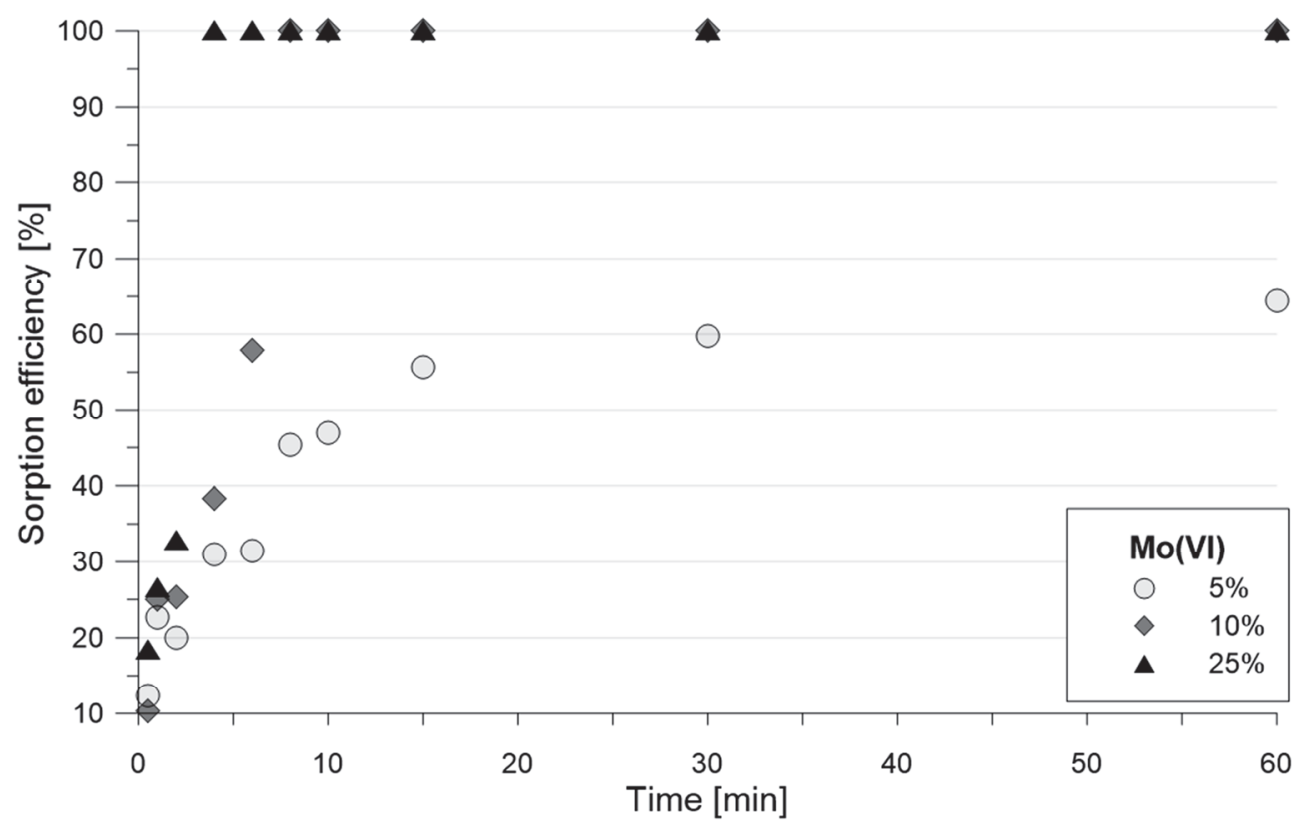

Fig. 6. The Mo(VI) sorption kinetics on $\mathrm{KFe}^{0}$ materials.

\subsection{Adsorption mechanisms}

To investigate the adsorption mechanisms, the XRD analysis was conducted on the $\mathrm{KFe}^{0} 25$ samples after the $\mathrm{Pb}(\mathrm{II})$ and $\mathrm{Mo}(\mathrm{VI})$ sorption experiments. As shown in Figure 7, the samples after reaction with $\mathrm{Pb}(\mathrm{II})$ and $\mathrm{Mo}(\mathrm{VI})$ do not show characteristic peaks attributed to $\mathrm{Fe}^{0}$, in contrast to the raw $\mathrm{KFe}^{0} 25$. The mechanism responsible for such phenomena is iron oxidation (Crane, Scott 2012). However, no characteristic peaks for iron oxides or iron hydroxides were found. This could be due to their amorphous or poor crystalline character, which was favored by fast precipitation, as well as the content of the oxidation products that can be below the XRD detection limit.

Zero-valent iron is susceptible to corrosion when exposed to the presence of oxygen (Eq. 4;5) - in aqueous media or air.

$$
\begin{aligned}
& 2 \mathrm{Fe}^{0}{ }_{(\mathrm{s})}+4 \mathrm{H}^{+}{ }_{\text {(aq) }}+\mathrm{O}_{2(\mathrm{aq})} \rightarrow 2 \mathrm{Fe}^{2+}+2 \mathrm{H}_{2} \mathrm{O}_{(\mathrm{l})} \\
& 2 \mathrm{Fe}^{0}{ }_{(\mathrm{s})}+2 \mathrm{H}_{2} \mathrm{O}_{(\mathrm{l})} \rightarrow 2 \mathrm{Fe}^{2+}+\mathrm{H}_{2(\mathrm{~g})}+2 \mathrm{OH}^{-}{ }_{(\mathrm{aq})}
\end{aligned}
$$

The kinetics of this process is very rapid and takes place even in controlled conditions. The corrosion product is Fe(II), which can turn into Fe(III) (Eq. 6;7) after further oxidation process.

$$
\begin{aligned}
& 2 \mathrm{Fe}^{2+}{ }_{(\mathrm{s})}+2 \mathrm{H}^{+}{ }_{\text {(aq) }}+1 / 2 \mathrm{O}_{2(\mathrm{aq})} \rightarrow 2 \mathrm{Fe}^{3+}+\mathrm{H}_{2} \mathrm{O}_{(\mathrm{l})} \\
& 2 \mathrm{Fe}^{2+}{ }_{(\mathrm{s})}+2 \mathrm{H}_{2} \mathrm{O}_{(\mathrm{l})} \rightarrow 2 \mathrm{Fe}^{3+}+\mathrm{H}_{2(\mathrm{~g})}+2 \mathrm{OH}^{-}{ }_{(\mathrm{aq})}
\end{aligned}
$$




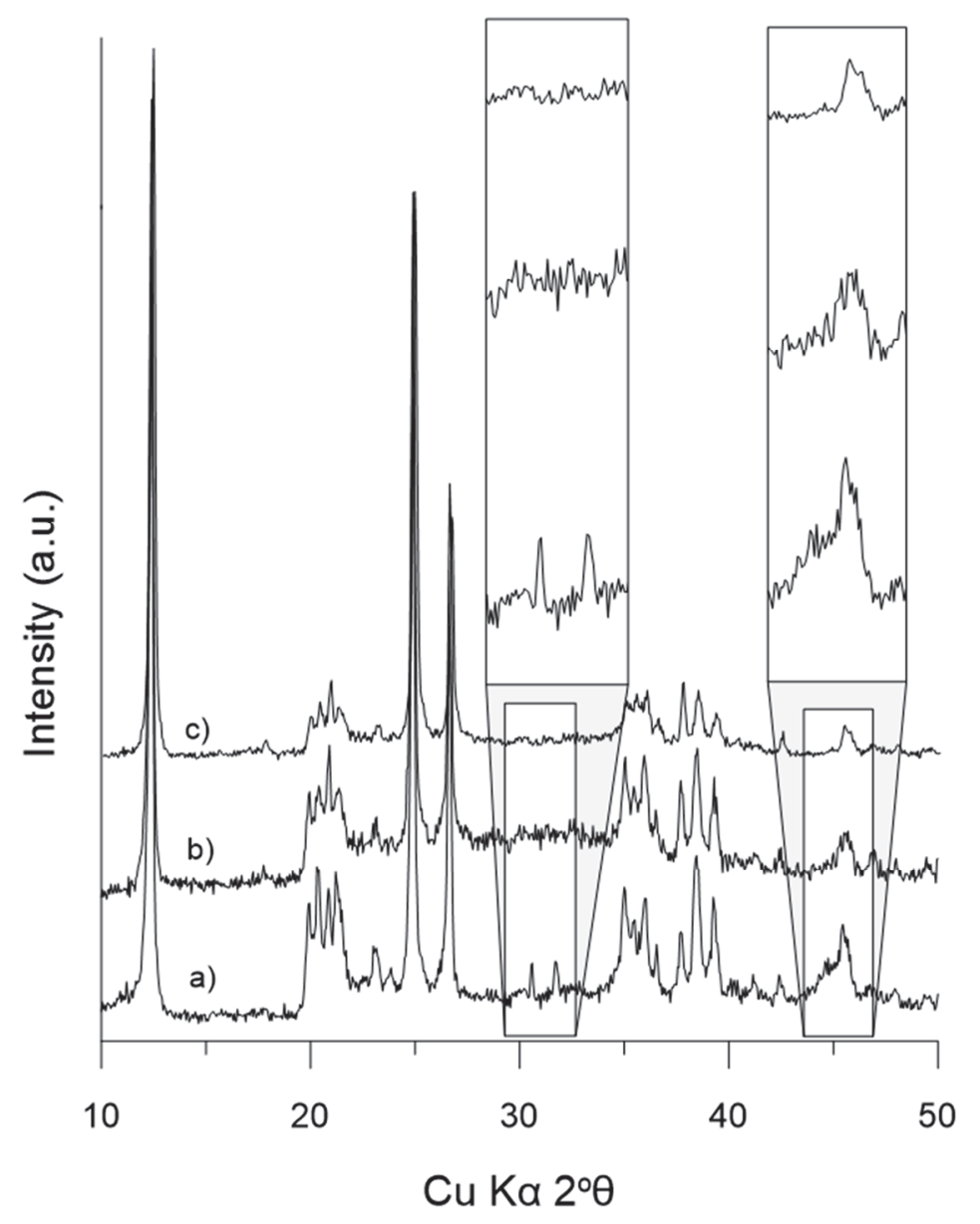

Fig. 7. The XRD patterns of (a) $\mathrm{KFe}^{0} 25$ and $\mathrm{KFe}^{0} 25$ after the (b) $\mathrm{Pb}$ (II) and (c) $\mathrm{Mo}$ (VI) adsorption experiment.

In such reactions, protons are consumed with the simultaneous production of hydroxyl ions, which increases the $\mathrm{pH}$. The $\mathrm{Fe}$ (II) and $\mathrm{Fe}$ (III) ions in aqueous solution can form precipitates, such as iron oxides and hydroxides. The iron in zero-valent form can be responsible for the reduction or sorption of contaminants because of its core-shell structure ( $\mathrm{Fe}^{0}$ 'core' and iron-oxide 'shell') created on a porous surface (Crane, Scott 2012). It was earlier reported that an oxidized shell covering the $\mathrm{Fe}^{0}$ particles starts to form at $\mathrm{pH}$ above 4.5 (Scott et al. 2011). Thus, as the initial $\mathrm{pH}$ in sorption experiments was set to 5.0, the presence of such iron particles exhibiting dual chemical character is highly possible.

As shown, the $\mathrm{Pb}$ (II) sorption increased with the loading amount of $\mathrm{Fe}^{0}$. An increasing amount of $\mathrm{Fe}^{0}$ in a sample increases the number of active sites on the material surface (Zhang 2013). The kaolinite supporting material prevented the aggregation of iron nanoparticles, providing more specific surface area for $\mathrm{Pb}(\mathrm{II})$ sorption (Zhang et al. 2010). 
$\mathrm{The} \mathrm{Pb}$ removal from aqueous solutions is not only a result of adsorption processes, but also a reduction in which $\mathrm{Pb}$ (II) is reduced simultaneously by the $\mathrm{KFe}^{0}$, while precipitation may also be involved (Arancibia-Miranda et al. 2014). The possible mechanism responsible for $\mathrm{Pb}(\mathrm{II})$ removal can be given by the following reaction (Ponder et al. 2000):

$$
2 \mathrm{Fe}^{0}+3 \mathrm{~Pb}^{2+}+4 \mathrm{H}_{2} \mathrm{O} \rightarrow 3 \mathrm{~Pb}^{0}+2 \mathrm{FeOOH}+2 \mathrm{H}^{+}
$$

The initial $\mathrm{pH}$ of the metal solutions was adjusted to 5.0 before adding the $\mathrm{KFe}^{0}$, and increased to approximately 9.0 during the reaction, mainly as a result of oxidation of the $\mathrm{Fe}^{0}$ by water (Kim et al. 2013). The high value of $\mathrm{pH}$ caused either negative charging of the $\mathrm{KFe}^{0}$ surface or $\mathrm{Pb}(\mathrm{OH})_{2}$ precipitation in the solution and on the surface of $\mathrm{KFe}^{0}$ (Zhang et al. 2010).

A large increase of $\mathrm{pH}$ after sorption experiments at low Mo(VI) concentrations can be connected with the transformation of $\mathrm{Fe}^{0}$ into $\mathrm{Fe}(\mathrm{II})$ and $\mathrm{Fe}$ (III), subsequently resulting in the formation of an iron hydroxide 'shell' ( $\mathrm{Li}$ et al. 2016). The Mo(VI) removal in such conditions may be due to both reduction by $\mathrm{Fe}^{0}$ and adsorption by iron hydroxide, but the reduction process seems to be dominant and can be described by the following reaction (Scott et al. 2011):

$$
\mathrm{MoO}_{4}{ }^{2-}+4 \mathrm{H}^{+}+2 \mathrm{e}^{-} \rightarrow \mathrm{MoO}_{2}+2 \mathrm{H}_{2} \mathrm{O}
$$

\section{Conclusions}

This work showed a successful kaolinite modification with zero-valent iron particles, which is suitable for $\mathrm{Pb}(\mathrm{II})$ and $\mathrm{Mo}(\mathrm{VI})$ removal from aqueous solutions.

The material synthesis resulted in $\mathrm{Fe}^{0}$ precipitation on the kaolinite surface, simultaneously with the presence of iron hydroxides, representing a 'core-shell' structure responsible for the material's sorption properties. The loading of $\mathrm{Fe}^{0}$ on kaolinite was confirmed by XRD and XRF analysis, while SEM analysis was conducted to show the $\mathrm{Fe}^{0}$ surface distribution.

The obtained material showed a significant increase of sorption capacity in relation to the raw kaolinite. The measurements showed that the increasing content of $\mathrm{Fe}^{0}$ increased the sorption of $\mathrm{Pb}(\mathrm{II})$ and $\mathrm{Mo}(\mathrm{VI})$. The application of the material with $25 \%$ content of $\mathrm{Fe}^{0}$ resulted in the highest sorption equal to approximately $500 \mathrm{mmol} \cdot \mathrm{kg}^{-1}$ for $\mathrm{Pb}(\mathrm{II})$ and $350 \mathrm{mmol} \cdot \mathrm{kg}^{-1}$ for $\mathrm{Mo}(\mathrm{VI})$.

$\mathrm{The} \mathrm{Pb}(\mathrm{II})$ kinetic experiment showed that all $\mathrm{Pb}(\mathrm{II})$ was removed after only $30 \mathrm{sec}$. The highest sorption rate in the case of $\mathrm{Mo}(\mathrm{VI})$ was observed for the $\mathrm{KFe}^{0} 25$ material. This confirmed the controlling role of $\mathrm{Fe}^{0}$ on the kinetics. A decrease of the $\mathrm{Fe}^{0}$ amount led to a lower sorption rate.

The sorption mechanisms were determined as a reduction induced by highly reactive $\mathrm{Fe}^{0}$ particles and adsorption on iron hydroxides. This was supported by $\mathrm{pH}$ measurements and solid-state analyses of the materials after adsorption processes. The observations were in agreement with earlier reports.

The overall results indicate that the application of $\mathrm{Fe}^{0}$-modified kaolinite can effectively remove $\mathrm{Pb}(\mathrm{II})$ and $\mathrm{Mo}(\mathrm{VI})$ from aqueous solutions, and thus can be an efficient and environmentally friendly substitute in water treatment technologies. 
Acknowledgements. This project was supported by the National Science Centre, Poland, under a research project awarded by Decision No. 2016/21/N/ST10/00390.

\section{References}

Arancibia-Miranda, N., Baltazar, S. E., García, A., Romero, A. H., Rubio, M. A., \& Altbir, D. (2014). Lead removal by nano-scale zero valent iron: surface analysis and $\mathrm{pH}$ effect. Materials Research Bulletin, 59, 341348. DOI: 10.1016/j.materresbull.2014.07.045.

Azizian, S. (2004) Kinetic models of sorption: a theoretical analysis. Journal of Colloid and Interface Science, 276, 47-52. DOI: 10.1016/j.jcis.2004.03.048.

Balan, E., Saitta, A. M., Mauri, F., \& Calas, G. (2001). First-principles modeling of the infrared spectrum of kaolinite. American Mineralogist, 86, 1321-1330. DOI: 10.2138/am-2001-11-1201

Bhattacharyya, K. G., \& Gupta, S. S. (2006). Adsorption of Fe(III) from water by natural and acid activated clays: Studies on equilibrium isotherm, kinetics and thermodynamics of interactions. Adsorption, 12(3), 185204. DOI:10.1007/s10450-006-0145-0.

Bhattacharyya, K. G., \& Gupta, S. S. (2007). Adsorptive accumulation of Cd(II), Co(II), Cu(II), $\mathrm{Pb}(\mathrm{II}), \mathrm{and}$ $\mathrm{Ni}(\mathrm{II})$ from water on montmorillonite: Influence of acid activation. Journal of Colloid and Interface Science, 310(2), 411-424. DOI: 10.1016/j.jcis.2007.01.080.

Crane, R., \& Scott T. (2012). Nanoscale zero-valent iron: Future prospects for an emerging water treatment technology. Journal of Hazardous Materials, 211-212, 112-125. DOI: 10.1016/j.jhazmat.2011.11.073.

Erdem, E., Karapinar, N., \& Donat R. (2004). The removal of heavy metal cations by natural zeolites. Journal of Colloid and Interface Science, 280( 2), 309-314. DOI: 10.1016/j.jcis.2004.08.028.

Grieger, K., Fjordbøge, A., Hartmann, N., Eriksson, E., Bjerg, P., \& Baun A. (2010). Environmental benefits and risks of zero-valent iron nanoparticles (nZVI) for in situ remediation: Risk mitigation or trade-off?. Journal of Contaminant Hydrology, 118, 165-183. DOI: 10.1016/j.jconhyd.2010.07.011.

Hudcova, B., Veselska, V., Filip, J., Cíhalova, S., \& Komarek M. (2016). Sorption mechanisms of arsenate on $\mathrm{Mg}-\mathrm{Fe}$ layered double hydroxides: A combination of adsorption modeling and solid state analysis. Chemosphere, 168, 539-548. DOI: 10.1016/j.chemosphere.2016.11.031.

Kim, S. A., Kamala - Kannan, S., Lee, K.- J., Park, Y.- J., Shea, P. J., Lee, W.- H., Kim, H.- M., \& Oh, B.- T. (2013). Removal of $\mathrm{Pb}$ (II) from aqueous solution by a zeolite-nanoscale zero-valent iron composite. Chemical Engineering Journal, 217, 54-60. DOI: 10.1016/j.cej.2012.11.097.

Koteja, A., Biskup, I., Góra, K., \& Matusik, J. (2015). Organo-kaolinite as an adsorbent of Cr(III) and Ni(II) ions. In Bajda T., Hycnar E., (Eds.) Sorbenty mineralne 2015: surowce, energetyka, ochrona środowiska, nowoczesne technologie, 131-143, Kraków, Wydawnictwo AGH.

Koteja, A., \& Matusik, J. (2015). Di- and triethanolamine grafted kaolinites of different structural order as adsorbents of heavy metals. Journal of Colloid and Interface Science, 455, 83-92. DOI: 10.1016/j.jcis.2015.05.027.

Leupin, O. X., \& Hug, S. J. (2005). Oxidation and removal of arsenic(III) from aerated groundwater by filtration through sand and zero-valent iron. Water Research, 39, 1729-1740. DOI: 10.1016/j.watres.2005.02.012.

Li, S., Wang, W., Liang, F., \& Zhang, W. (2016). Heavy metal removal using nanoscale zero-valent iron (nZVI): Theory and application. Journal of hazardous materials, 322, 163-171. DOI: 10.1016/j.jhazmat.2016.01.032.

Liu, J., Yuan, S. W., Du, H. Y., \& Jiang, X. Y. (2014). Adsorption of Cd(II) from Aqueous Solution by Magnetic Graphene. Advanced Materials Research, 881-883, 1011-1014. DOI: 10.4028/www.scientific.net/AMR.881883.1011 .

Matusik, J. (2014). Arsenate, orthophosphate, sulfate, and nitrate sorption equilibria and kinetics for halloysite and kaolinites with an induced positive charge. Chemical Engineering Journal, 246, 244-253. DOI: 10.1016/j.cej.2014.03.004.

Meunier, N., Drogui, P., Montane, C., Hausler, R., Mercier, G., \& Blais, J. F. (2006). Comparison between electrocoagulation and chemical precipitation for metals removal from acidic soil leachate. Journal of Hazardous Materials, 137, 581-590. DOI: 10.1016/j.jhazmat.2006.02.050

Oehmen, A., Viegas, R., Velizarov, S., Reis, M. A. M., \& Crespo, J. G. (2006). Removal of heavy metals from drinking water supplies through the ion exchange membrane bioreactor. Desalination, 199, 405-407. DOI: 10.1016/j.desal.2006.03.091. 
Patnukao, P., Kongsuwan, A., \& Pavasant, P. (2008). Batch studies of adsorption of copper and Pb(II) on activated carbon from Eucalyptus camaldulensis Dehn, bark. Journal of Environmental Sciences, 20, 1028-1034. DOI: 10.1016/S1001-0742(08)62145-2.

Ponder, S., Darab, J., \& Mallouk, T. (2000). Remediation of $\mathrm{Cr}(\mathrm{VI})$ and $\mathrm{Pb}(\mathrm{II})$ Aqueous Solutions Using Supported, Nanoscale Zero-valent Iron. Environmental Science \& Technology, 34, 2564-2569. DOI: $10.1021 /$ es 9911420 .

Prabu, D., \& Parthiban, R. (2013). Synthesis and characterization of nanoscale zero-valent iron (NZVI) nanoparticles for environmental remediation. Asian Journal of Pharmacy and Technology, 3(4), 181-184.

Ramos, M. A. V., Yan, W. L., Li, X. Q., Koel, B. E., \& Zhang, W. X. (2009). Simultaneous oxidation and reduction of arsenic by zero-valent iron nanoparticles: understanding the significance of the core-shell structure. Journal of Physical Chemistry C, 113, 14591-14594. DOI:10.1021/jp9051837.

Ren, X. M., Li, J. X., Tan, X. L., \& Wang, X. K. (2013). Comparative study of graphene oxide, activated carbon and carbon nanotubes as adsorbents for copper decontamination. Dalton Transactions, 42, 5266-5274. DOI: 10.1039/C3DT32969K.

Rui, M., Buruberri, L. H., Seabra, M. P., \& Labrincha, J. A. (2016). Novel porous fly-ash containing geopolymer monoliths for lead adsorption from wastewaters, Journal of Hazardous Materials, 318, 631-640. DOI: 10.1016/j.jhazmat.2016.07.059.

Rybka, K. (2017). Efektywność oczyszczania roztworów wodnych z wybranych anionów przez nanokompozyty otrzymane na bazie kaolinitu ze złoża Maria III, (Efficiency of selected anions removal from aqueous solutions by nanocomposites derived from Maria III kaolinite.), MSc thesis, AGH University of Science and Technology, Krakow, Poland. [in Polish].

Saada, A., Breeze, D., Crouzet, C., Cornu, S., \& Baranger, P. (2003). Adsorption of arsenic(V) on kaolinite and on kaolinite-humic acid complexes: Role of humic acid nitrogen groups. Chemosphere, 51(8), 757-763. DOI: 10.1016/S0045-6535(03)00219-4.

Scott, T. B., Popescu, I. C., Crane, R. A., \& Noubactep, C. (2011). Nano-scale metallic iron for the treatment of solutions containing multiple inorganic contaminants. Journal of hazardous materials, 186, 280-287. DOI: 10.1016/j.jhazmat.2010.10.113.

Suraj, G., Iyer, C. S. P., \& Lalithambika, M. (1998). Adsorption of cadmium and copper by modified kaolinites. Applied Clay Science, 13(4), 293-306. DOI: 10.1016/S0169-1317(98)00043-X.

Szala, B., Bajda, T., Matusik, J., Zięba, K., \& Kijak, B. (2015). BTX sorption on Na-P1 organo-zeolite as a process controlled by the amount of adsorbed HDTMA. Microporous and Mesoporous Materials, 202, 115123. DOI: 10.1016/j.micromeso.2014.09.033.

Unuabonah, E. I., Adebowale, K. O., Olu-Owolabi, B. I., Yang, L. Z., \& Kong L. X. (2008). Adsorption of Pb(II) and $\mathrm{Cd}(\mathrm{II})$ from aqueous solutions onto sodium tetraborate-modified kaolinite clay: equilibrium and thermodynamic studies. Hydrometallurgy, 93, 1-9. DOI: 10.1016/j.hydromet.2008.02.009.

Üzüm, Ç., Shahwan, T., Eroğlu, A. E., Hallam, K. R., Scott, T. B., \& Lieberwirth, I. (2009). Synthesis and characterization of kaolinite-supported zero-valent iron nanoparticles and their application for the removal of aqueous $\mathrm{Cu}^{2+}$ and $\mathrm{Co}^{2+}$ ions. Applied Clay Science, 43(2), 172-181. DOI: 10.1016/j.clay.2008.07.030.

Üzüm, Ç., Shahwan, T., Eroğlu, A. E., Lieberwirth, I., Scott, T. B., Hallam, K. R. (2008). Application of zerovalent iron nanoparticles for the removal of aqueous $\mathrm{Co}^{2+}$ ions under various experimental conditions. The Chemical Engineering Journal, 144(2), 213-220. DOI: 10.1016/j.cej.2008.01.024.

Wang, C., \& Zhang, W. (1997). Synthesizing nanoscale iron particles for rapid and complete dechlorination of TCE and PCBS. Environmental Science \& Technology, 31, 2154-2156. DOI: 10.1021/es970039c.

Wang, J., Liu, G., Li, T., Zhou, C., \& Qi, C. (2015). Zero-Valent Iron Nanoparticles (NZVI) Supported by Kaolinite for CuII and NiII Ion Removal by Adsorption: Kinetics, Thermodynamics, and Mechanism. Australian Journal of Chemistry., 68, 1305-1315. DOI: 10.1071/CH14675.

Xu, D., Tan, X., Chen, C., \& Wang, X. (2008). Removal of Pb(II) from aqueous solution by oxidized multiwalled carbon nanotubes. Journal of Hazardous Materials, 154, 1-3, 407-416. DOI: 10.1016/j.jhazmat.2007.10.059.

Yan, W., Ramos, M. A. V., Koel, B. E., \&. Zhang, W. X. (2012). As(III) sequestration by iron nanoparticles: study of solid-phase redox transformations with X-ray photoelectron microscopy. Journal of Physical Chemistry C, 116, 5303-5311. DOI: 10.1021/jp208600n.

You, Y., Vance, G. F., \& Zhao, H. (2001). Selenium adsorption on Mg-Al and Zn-Al layered double hydroxides. Applied Clay Science, 20, 13-25. DOI: 10.1016/S0169-1317(00)00043-0.

Zachara, J. M., Cowan, C. E., Schmidt, R. L., \& Ainsworth, C. C. (1988). Chromate adsorption on kaolinite. Clays and Clay Minerals, 36(4), 317-326. DOI: 10.1346/CCMN.1988.0360405. 
Zhang, Y.-Y., Jiang, H., Zhang, Y., \& Xie, J.-F. (2013). The dispersity-dependent interaction between montmorillonite supported nZVI and Cr(VI) in aqueous solution. Chemical Engineering Journal, 229, 412419. DOI: 10.1016/j.cej.2013.06.031.

Zhang, X., Lin, S., Chen, Z., Megharaj, M., \& Naidu, R. (2010). Kaolinite supported nanoscale zero-valent iron for removal of $\mathrm{Pb} 2$ from aqueous solution: Reactivity, characterization and mechanism. Water Research, 45(11), 3481-3488. DOI: 10.1016/j.watres.2011.04.010.

Zhang, X., Lin, S., Lu, X.Q., \& Chen, Z. L. (2010). Removal of Pb(II) from water using natural kaolin loaded with synthesized nanoscale zero-valent iron. The Chemical Engineering Journal 163(3), 243-248. DOI: 10.1016/j.cej.2010.07.056.

Zhang, S. Q., \& Hou, W. G. (2008). Adsorption behavior of Pb(II) on montmorillonite. Colloids and Surfaces A: Physicochemical and Engineering Aspects, 320(1-3), 92-97. DOI: 10.1016/j.colsurfa.2008.01.038.

Zondervan, E., \& Roffel, B. (2007). Evaluation of different cleaning agents used for cleaning ultra filtration membranes fouled by surface water. Journal of Membrane Science, 304, 40-49. DOI: 10.1016/j.memsci.2007.06.041. 